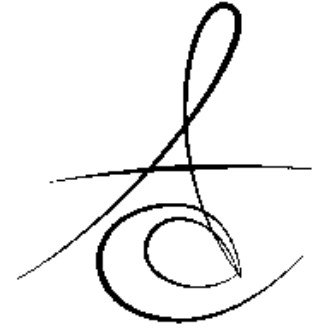

Makale Kodu/Article code: 2550

Makale Gönderilme tarihi: 14.01.2016

Kabul Tarihi: 28.03.2016

\title{
FARKLI İÇECEKLERDE BEKLETİLEN YUMUŞAK ASTAR MATERYALLERİNİN RENK STABİLITTESİNİN İN VİTRO OLARAK DEĞERLENDİRİLMESİ ${ }^{*}$
}

\section{IN VITRO COLOR STABILITY OF SOFT DENTURE LINERS AFTER STORAGE IN DIFFERENT BEVERAGES ${ }^{*}$}

\author{
Yrd. Doç. Dr. Canan AKAY* $\quad$ Yrd. Doç. Dr. Pınar ÇEVİK** \\ Uzm. Dr. Ayşe Nurcan DUMAN**
}

\section{öz}

Amaç: Bu çalışmanın amacı farklı içecek solüsyonlarında (çay, kahve, portakal suyu, distile su) bekletilen yumuşak astar materyallerinin renk değişiminin değerlendirilmesidir.

Gereç ve yöntemler: Çalışmamızda ufijel, viskojel, elitesoft ve kerr olmak üzere dört farklı yumuşak astar materyali değerlendirilmiştir. Yumuşak astar materyallerinin oluşturduğu her bir örnek grubundan 20 şer adet örnek $15 \mathrm{~mm}$ çapında ve $2 \mathrm{~mm}$ kalınlığında disk şeklinde hazırlandı. Beş adet örnek her bir solüsyonda bekletildi. Renk değişimi spektrofotometre cihazı ile başlangıçta, 24 saat ve 7 gün sonunda içeceklerde bekletilerek ölçüldü. İstatistikler tek yönlü varyans analizi ve post hoc tukey testi ile değerlendirildi.

Bulgular: Tek yönlü varyans analizi ve bağımlı T testi (paired T) sonuçlarına göre; 24 saat ve bir haftalık ölçümler sırasında ve yumuşak astar materyalleri ile solüsyonlar arasındaki fark anlamlı bulunmuştur. $(p<0,05) 24$ saatlik bekletme süresi sonunda post hoc sonuçlarına göre; en yüksek $\Delta \mathrm{E}$ değeri viscogel kahve grubunda gözlenirken, en düşük $\Delta \mathrm{E}$ değeri ufigel portakal suyu grubunda gözlenmiştir. Bir haftalık bekletme süresi sonunda, yapılan post hoc analizine göre; en yüksek $\Delta \mathrm{E}$ değeri kerr çay grubunda gözlenirken en düşük $\Delta \mathrm{E}$ değeri ufigel portakal suyu grubunda gözlenmiştir.

Sonuç: Renk stabilitesi, materyalin yıpranması ve zarar görmesi hakkında klinisyenlere fikir veren bir belirteçtir. Bu çalışmada, test edilen materyallerin uygulanıldığı hastalar, bu renk değiş̧ikliği hakkında bilgilendirilmelidir.

Anahtar kelimeler: Yumuşak astar, renk stabilitesi, içecekler

\section{ABSTRACT}

Aim: The aim of this study was to evaluate the colour change of soft denture liners after storage in coffee, tea, orange juice, distilled water.

Materials and methods: Four liners (ufigel, viscogel, elitesoft and kerr) were evaluated in this study. Twenty disc-shaped samples, with uniform size of $15 \mathrm{~mm}$ diameter and $2 \mathrm{~mm}$ thickness were obtained for each solution. Five samples were stored in each solutions. The colour change was measured in a reflection spectrophotometer before and after 1 hour and 7 days of storage in beverages. Data were statistically analyzed using One way ANOVA and post hoc Tukey tests.

Results: One-way ANOVA and dependent t-test ( paired T), according to the results; It found a significant difference between 24 hours and a weekly measurements during and soft lining materials and solutions. ( $P<0.05$ ), according to a post hoc results at the end of the 24-hour waiting period; The highest value $\Delta \mathrm{E}$ viscogel coffee group with the lowest value was observed in ufigel group was observed in orange juice. After one-week waiting period, by post hoc analysis done; The highest value $\Delta \mathrm{E}$ kerr lowest value was observed in the tea group were observed in the orange juice group ufigel

Conclusion: Color stability of soft liners is an important indicator for clinicians of aging or damaging. The patients which had been applied the tested materials must be advised about this discoloration.

Key words: soft liners, color stability, bevereges

\footnotetext{
${ }^{\text {E} E s k i s ̧ e h i r ~ O s m a n g a z i ~ U ̈ n i v e r s i t e s i, ~ D i s ̧ ~ H e k i m l i g ̆ i ~ F a k u ̈ l t e s i, ~ P r o t e t i k ~ D i s ̧ ~ T e d a v i s i ~ A D ~}$

${ }^{* *}$ Gazi Üniversitesi, Diş Hekimliği Fakültesi, Protetik Diş Tedavisi AD

${ }^{\ddagger}$ Bu makale Antalya'da düzenlenen 22.Uluslararasi Türk-prostodonti ve implantoloji derneği

bilimsel-kongresinde 12-15 Kasım 2015 tarihinde sözlü bildiri olarak sunulmuştur
} 


\section{GİRIŞ}

Yumuşak astar materyalleri maksillofasiyal ve tam protezlerde tutuculuğu artırmak, aşırı rezorbe ve bıçak sırtı kretlerde, kemik andırkatları, ince mukozaya sahip, ağız kuruluğu olan hastalarda destek dokuların tedavisinde hastaya konfor sağlamak amacıyla sıklıkla kullanılır ${ }^{1-4}$.

Yumuşak astar materyalleri kullanılarak yapılan tedavinin pahalı olmaması, invaziv bir tedavi olmaması, kullanım sırasında otopolimerize materyallerin hazırlanmasında tek bir seans olması, hastanın yaşam kalitesini artırması gibi sebeplerle dental rekonstrüksiyon gereken kişilerde tedavi memnuniyetini artırmaktadır ${ }^{5}$.

Farklı mekanik özellikler ve klinik davranış sergileyen çok sayıda yumuşak astar materyali mevcuttur. Bunlar içerisinde sıklıkla kullanılanlar, plastisize akrilik ve silikon elastomerlerdir. Akrilik esaslı yumuşak astar materyallerinin yapısındaki plastizerler akriliğe yumuşaklık sağlar ve zamanla plastizörlerini kaybederek sertleşirler. Silikon elastomerler de ise dışsal bir plastizere gerek yoktur ve bu yüzden uzun süre yumuşaklığını korurlar6.

Her iki çeşit yumuşak astar maddesinin oda ISIsında ya da ısıyla polimerize olarak sertleşeni mevcuttur; her birinin plastisizer yüzdesi, çapraz bağlantı ajanı, katalist ve doldurucu yüzdeleri değişik oranlara sahiptir. Bunlar arasında, sıklıkla uzun süreli başarılı uygulamaları nedeniyle silikon elastomerlerin ISı ile polimerize olan grubu tercih edilmektedir ${ }^{7,8}$.

Dental materyaller için en önemli özelliklerden birisi renk stabilitesidir. Protetik tedavi amaçlı kullanılan materyallerin büyük bir kısmının sıvı absorbiyon ve adsorbsiyon eğilimlerinden dolayı renk değişimine uğrayabilir. Renk stabilitesi hastada estetik görünümün devamlılığını sağlarken aynı zamanda dental materyalin yıpranması ve zarar görmesi hakkında da diş hekimine fikir vermektedir. Bu sebeple özellikle uzun süreli yumuşak astar materyallerinde renk stabilitesi daha fazla önem kazanmaktadır. Yaşlandırma işlemlerinin, beslenme alışkanlıklarının, renklendirici gıdaların ve temizleme ajanlarının yumuşak astar materyallerinin renk stabiliteleri üzerinde etkili olduğu birçok çalışmada saptanmış ve akrilik esaslı yumuşak astar materyallerinin silikon esaslı olanlara kıyasla daha düşük renk stabilitesi gösterdiği rapor edilmiştir ${ }^{1-3,9-11}$.

$\mathrm{Bu}$ çalışmada, örneklere ait renk değişimleri Munsell renk sistemi ve CIELAB sistemi esas alınarak yapılmıştır. L* değeri, materyale ait rengin açıklığını ifade ederken, a* değeri yeşilden kırmızıya doğru olan renk değişimini ve $b^{*}$ değeri sarıdan maviye olan renk değişimini ifade eder ${ }^{12}$.

Bu çalışmanın amacı günlük olarak sıklıkla tüketilen bazı içeceklerin yumuşak astar materyallerinin renk stabilitesi üzerine etkilerinin incelenmesidir ${ }^{7}$.

\section{GEREÇ VE YÖNTEM}

Çalışmada kullanılan yumuşak astar materyalleri (ufigel, viscogel, elite soft, kerr) ve 3 farklı içecek solüsyonu (kahve, çay, portakal suyu ile kontrol grubu olarak kullanılan distile su ) Tablo 1 de gösterilmiştir

Tablo 1. Çalışmada kullanılan materyal özellikleri

\begin{tabular}{|c|c|c|c|}
\hline $\begin{array}{c}\text { Yumuşak } \\
\text { astar } \\
\text { materyali }\end{array}$ & $\begin{array}{c}\text { Üretici } \\
\text { Firma }\end{array}$ & $\begin{array}{c}\text { Polimerizas } \\
\text { yon Şekli }\end{array}$ & İçeriği \\
\hline Kerr & $\begin{array}{c}\text { KERR ITALIA } \\
\text { Via Passanti, } \\
\text { Scafati (SA)- } \\
\text { Italy }\end{array}$ & $\begin{array}{c}\text { Oda Isında 12 } \\
\text { saat }\end{array}$ & $\begin{array}{c}\text { Dibutyl Phtalate } \\
\text { (DBP) } \\
\text { Ethyl Alcohol } \\
\text { Methyl Salicylate }\end{array}$ \\
\hline Viscogel & $\begin{array}{c}\text { Dentsplay De } \\
\text { Trey GmbH } \\
\text { Germany }\end{array}$ & $\begin{array}{c}\text { Oda Isında 12 } \\
\text { saat }\end{array}$ & $\begin{array}{c}\text { Polietilmetakrilat, } \\
\text { etil alkol } \\
\text { Ayırıl: mineral } \\
\text { yağ } \\
\text { Sitrit ester } \\
\text { plastiserleri }\end{array}$ \\
\hline Elite-Soft & $\begin{array}{c}\text { Elite Soft } \\
\text { relining, } \\
\text { Kettenbach, } \\
\text { Almanya }\end{array}$ & $\begin{array}{c}40-45^{\circ} \mathrm{C} \text { de 10 } 10 \\
\text { dk ekstromattal } \\
\text { polimerize edild }\end{array}$ & $\begin{array}{c}\text { Polivinil siloksan, } \\
\text { Platinyum katalist }\end{array}$ \\
\hline Ufi Gel P & $\begin{array}{c}\text { Voco, } \\
\text { Cuxhaven, } \\
\text { Almanya }\end{array}$ & $\begin{array}{c}40-45^{\circ} \mathrm{C} \text { de } 15 \\
\text { dk ekstromatta } \\
\text { polimerize } \\
\text { edildi. }\end{array}$ & $\begin{array}{c}\text { Modifiye } \\
\text { polidimethil } \\
\text { siloksan and } \\
\text { platinyum katalist }\end{array}$ \\
\hline
\end{tabular}

Yumuşak astar materyallerinin oluşturduğu her bir örnek grubundan 20 şer adet örnek $15 \mathrm{~mm}$ çapında ve $2 \mathrm{~mm}$ kalınlığında disk şeklinde paslanmaz çelik kalıplar içerisinde üretici firmanın önerileri doğrultusunda hazırlandı. Hazırlanan araştırma örnekleri test öncesinde $37^{\circ} \mathrm{C} \pm 1{ }^{\circ} \mathrm{C}$ de 24 saat süre ile distile suda bekletildiler.

Hazırlanmış olan örnekler dört gruba ayrılarak, $5^{\prime}$ er adet örnek hazırlanmış olan solüsyonlara 1. grup çaya (Yellow Label Tea, Lipton, İstanbul, Türkiye), 2. grup kahveye (Nescafe Classic, Nestle, Karacabey, Bursa, Türkiye), 3. grup portakal suyuna (Cappy, Yenibosna, İstanbul, Türkiye), 4. grup kontrol grubu olarak distile suya daldırıldı. Çalışmada kullanılan içecek solüsyonları Tablo 2'de gösterilmiştir.

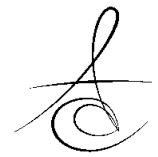


Tablo 2. Test edilen içecek solüsyonları

\begin{tabular}{|l|c|l|}
\hline $\begin{array}{l}\text { İçecek } \\
\text { materyali }\end{array}$ & Ürün adı Ürüthrefiti Firma \\
\hline Çay & Lipton & $\begin{array}{l}\text { Yellow Label Tea, } \\
\text { Lipton, İstanbul, } \\
\text { Türkiye }\end{array}$ \\
\hline Kahve & $\begin{array}{l}\text { Nescafe- } \\
\text { Classic }\end{array}$ & $\begin{array}{l}\text { Nescafe Classic, Nestle, } \\
\text { Karacabey, Bursa, } \\
\text { Türkiye }\end{array}$ \\
\hline Portakal suyu & Cappy & $\begin{array}{l}\text { Cappy, Yenibosna, } \\
\text { İstanbul, Türkiye }\end{array}$ \\
\hline
\end{tabular}

Standart solüsyonlar hazırlamak amacıyla çay solüsyonu için, $150 \mathrm{ml}$ kaynayan suya 1 poşet atılıp 10 dakikalık bekleme süresinden sonra, kahve ise $200 \mathrm{ml}$ kaynayan suya 2 gr'lik 1 paket kahve karıştırılarak 10 dakikalık bekleme süresinden sonra kahve solüsyonu filtre edilerek solüsyon hazır hale geldi. Kontrol grubu örnekleri ise çalışma süresi boyunca distile suda bekletildi. Hazırlanmış olan solüsyonlar her gün yenilendi ve üzeri kapatılarak muhafaza edildi.

Örneklerin ilk renk ölçümleri örnek hazırlanmasının hemen ardından yapılmış olup ikinci renk ölçümleri 24 saat sonunda ve üçüncü renk ölçümleri ise 1 hafta sonunda yapılmıştır. Hazırlanan her bir örneğin ölçüm işlemi dijital bir spektrofotometre (VITA Easy shade Compact Advance 4.0, VITA Zahnfabrik $\mathrm{H}$. Rauter $\mathrm{GmbH} \&$ Co.KG)(Resim 1) yardımı ile yapılmıştır. Kullanmış olduğumuz spektrofotometre; vitapan classic ve vitapan 3D-master renk sistemlerinde ölçüm yapabilen, $15-40{ }^{\circ} \mathrm{C}$ ISI aralığına sahip, White high power led ışık cinsine sahip, şarj edilebilir Li-lon pil ile çalışma gibi teknik özelliklere sahiptir. Örneklerin $\Delta \mathrm{E}$ değerleri aşağıdaki formül kullanılarak hesaplanmıştır:

$\Delta \mathrm{E}=\left(\mathrm{L} 1^{*}-\mathrm{L} 2^{*}\right)^{2}+\left(\mathrm{a} 1^{*}-\mathrm{a} 2^{*}\right)^{2}+\left(\mathrm{b} 1^{*}-\mathrm{b} 2^{*}\right)^{21 / 2}$

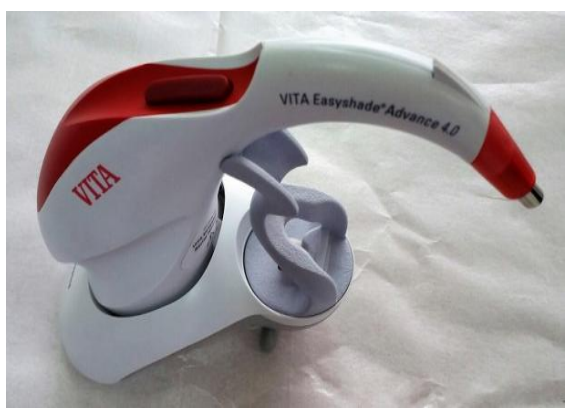

Resim 1. Hazırlanan örneklerin renk ölçüm işleminde kullanilan spektrofotometre (VITA Easy shade Compact Advance 4.0, VITA Zahnfabrik H.Rauter GmbH \& Co.KG)
Çalışmada elde edilen bulguların istatistiksel analizinde yumuşak astar materyallerine içecek solüsyonnlarının renk değişimine etkisinin değerlendirilmesinde tek yönlü Anova ve Post hoc TUKEY testi, uygulama süresinin etkisinin incelenmesinde bağımlı $t$ testi kullanıldı. Sonuçlar \%95'lik güven aralığında ve $\mathrm{p}<0,05$ anlamlılık düzeyinde değerlendirildi.

\section{BULGULAR}

One way Anova ve bağımlı $\mathrm{T}$ testi (paired $\mathrm{T}$ ) sonuçlarına göre; 24 saat ve bir haftalık ölçümler sırasında ve yumuşak astar materyalleri ile solüsyonlar arasındaki fark anlamlı bulunmuştur. $(p<0,05)$ (Tablo $3,4) 24$ saatlik bekletme süresi sonunda post hoc sonuçlarına göre; en yüksek $\Delta \mathrm{E}$ değeri viscogel kahve grubunda gözlenirken en düşük $\Delta \mathrm{E}$ değeri ufigel portakal suyu grubunda gözlenmiştir. Bir haftalık bekletme süresi sonunda, yapılan post hoc analizine göre; en yüksek $\Delta \mathrm{E}$ değeri kerr çay grubunda gözlenirken en düşük $\Delta \mathrm{E}$ değeri ufigel portakal suyu grubunda gözlenmiştir(Grafik 1).

Bir haftalık solüsyonda bekletilme sonuçlarına göre Viskojel yumuşak astar materyali için portakal suyunda bekletilen grup istatistiksel olarak diğer gruplardan farklı ve düşük değere sahiptir. Ufijel için çay ve portakal suyunda bekletilen örnekler istatistiksel olarak kahve ve distile suda bekletilen örneklerden farklı ve düşük değere sahiptir (Tablo 5,6). Bir haftalık bekletme süresi sonuçlarına göre örneklere ait renklenme fotoları Resim 2'de mevcuttur.

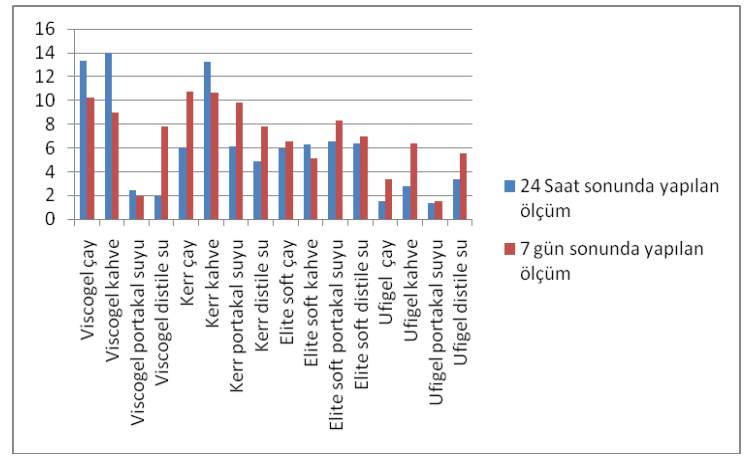

Grafik 1. Bir haftalık ve 24 saatlik ölçümler sonunda elde edilen renk değişim değerleri 
Tablo 3. Farklı solüsyonlarda bekletilen yumuşak astar materyallerinin 1 haftalık bekletme süresi sonundaki renk değişimi

\begin{tabular}{|l|l|l|l|l|}
\hline & Çay & Kahve & Cappy & Distile \\
\hline Viscojel & ab & A & a & a \\
\hline Kerr & b & B & b & a \\
\hline $\begin{array}{l}\text { Elite } \\
\text { soft }\end{array}$ & a & C & b & a \\
\hline ufijel & c & D & a & a \\
\hline
\end{tabular}

Tukey HSD çoklu karşılaştırma sonuçlarına göre; ayn sütundaki farklı harfler anlamlı farkııı̆ı ifade etmektedir.

Tablo 4. Tukey HSD çoklu karşılaştırma testine göre, her bir yumuşak astar materyalinin farklı solüsyonlarda bekletildikten sonraki renk değişimler

\begin{tabular}{|l|l|l|l|l|}
\hline & Viscojel & Kerr & $\begin{array}{l}\text { Elite } \\
\text { soft }\end{array}$ & Ufijel \\
\hline Çay & a & A & a & a \\
\hline Kahve & a & A & a & b \\
\hline Cappy & b & A & a & a \\
\hline Distile & a & A & a & b \\
\hline
\end{tabular}

Tukey HSD çoklu karşılaşıırma sonuçlarına göre; aynı sütundaki farklı harfler anlamlı farklıı̆ı ifade etmektedir

Tablo 5. One way ANOVA sonuçlarına göre grupların ortalama değerleri (1 günlük ölçüm sonunda)

\begin{tabular}{|l|r|r|}
\hline \multicolumn{1}{|c|}{ Grup } & $\begin{array}{r}\text { Örnek } \\
\text { sayısı }\end{array}$ & \multicolumn{1}{c|}{ Ortalama } \\
\hline viscoçay & 5 & 13,3575 \\
\hline viscokahve & 5 & 14,0126 \\
\hline viscocappy & 5 & 2,4299 \\
\hline viscodistile & 5 & 1,9743 \\
\hline kerrçay & 5 & 6,0093 \\
\hline kerrkahve & 5 & 13,2255 \\
\hline kerrcappy & 5 & 6,1664 \\
\hline kerrdistile & 5 & 4,8956 \\
\hline eliteçay & 5 & 5,9591 \\
\hline elitekahve & 5 & 6,3185 \\
\hline elitecappy & 5 & 6,5461 \\
\hline elitedistile & 5 & 6,4028 \\
\hline ufiçay & 5 & 1,5200 \\
\hline ufikahve & 5 & 2,8200 \\
\hline uficappy & 5 & 1,3267 \\
\hline ufidistile & 5 & 3,3400 \\
\hline Total & 80 & 6,0190 \\
\hline
\end{tabular}

Tablo 6: One way ANOVA sonuçlarına göre grupların ortalama değerleri (1 haftalık ölçüm sonunda)

\begin{tabular}{|l|l|l|}
\hline Grup & $\begin{array}{l}\text { Örnek } \\
\text { sayısı }\end{array}$ & Ortalama \\
\hline viscoçay & 5 & 10,2497 \\
\hline viscokahve & 5 & 8,9409 \\
\hline viscocappy & 5 & 1,9808 \\
\hline viscodistile & 5 & 7,7815 \\
\hline kerrçay & 5 & 10,7383 \\
\hline kerrkahve & 5 & 10,6594 \\
\hline kerrcappy & 5 & 9,8465 \\
\hline kerrdistile & 5 & 7,8019 \\
\hline eliteçay & 5 & 6,5970 \\
\hline elitekahve & 5 & 5,1351 \\
\hline elitecappy & 5 & 8,2923 \\
\hline elitedistile & 5 & 6,9587 \\
\hline ufiçay & 5 & 3,3400 \\
\hline ufikahve & 5 & 6,4200 \\
\hline uficappy & 5 & 1,5200 \\
\hline ufidistile & 5 & 5,5800 \\
\hline Total & 80 & 6,9901 \\
\hline
\end{tabular}

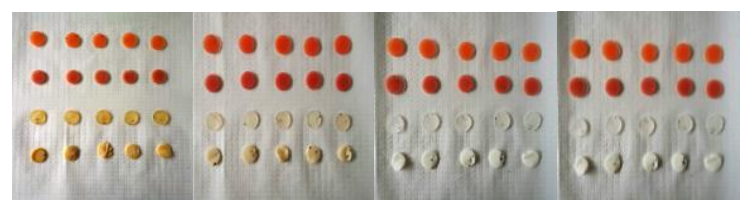

Resim 2. Bir haftalık ölçüm sonucunda renk değerlendirilmesi yapılan yumuşak astar materyalleri sırasıyla; kahve, çay portakal suyu ve distile su grubu örnekleri

\section{TARTIŞMA}

Yumuşak astar materyallerinin renk değişimi göstermemesi hastanın memnuniyeti ve mevcut olan protezini kabul etmesini etkileyen önemli unsurlardan biridir $^{13}$.

Günlük kullanım içerisinde, yumuşak astar materyalleri tükürük bileşenleri, oral kavitedeki ISI değişimleri, hastanın beslenme alışkanlıklarına bağlı olarak renklendirici gıdalar, ilaçlar, tütün ürünleri ve dental temizleme materyallerine maruz kalmaktadır ${ }^{5,14}$.

Günümüzde yumuşak astar materyallerinin fiziksel ve kimyasal özellikleri çok gelişmiş olmasına karşı halen su emilimi, çözünürlük ve renk stabilitesini koruyamama gibi dezavantajları bulunmaktadır. Yumuşak astar maddelerinde herhangi bir renklendirici solüsyona maruz bırakılmadan gözlenen renk değişikliği yumuşak astar materyalinin kimyasal yapısındaki değişiklikleri gösteren bir belirtidir ${ }^{1,15}$.

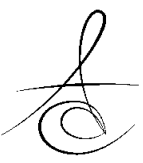


Ancak günümüzde hala yumuşak astar materyallerinin renk değiştirme mekanizması bilinmemektedir; pigmentlerindeki değişiklikler ya da elastomerin renk değiştirmesi çoğu zaman sorumlu tutulmaktadır $^{16,17}$.

Hollis ve arkadaşları ${ }^{18}$ dental protez kaide materyallerini kahve, kola ve üzüm suyuna tabi tuttuktan sonra piyasada kullanılan çeşitli protez temizleyici ajanlar içinde beklettikleri çalışmalarında 8 hafta sonunda NBS sistemine göre renk değişim kriterini $6<$ $\Delta \mathrm{E}<12$ için çok, $\Delta \mathrm{E}>12$ için çok fazla olarak tanımlamışlardır. Renk farkı değerinin $(\Delta E)$ yorumlanmasında National Bureau of Standarts (NBS) tarafinca belirlenen. NBS verilerinin saptanmasında 'NBS $=\Delta \mathrm{E} \times 0,92$ ' formülü kullanılmıştır. NBS değerleri literatürde bazı yazarlar tarafından dikkate alınmıştır. NBS sistemine ait renk değişimi için öngörülen değerler Tablo 7'de açıklanmıştır ${ }^{3}$.

Tablo 7. NBS tarafından belirlenen renk farkı tanımlama kriterleri

\begin{tabular}{lc}
\hline $\begin{array}{l}\text { Renk farklı̆̆ı̆ } \\
\text { tanımlama }\end{array}$ & $\begin{array}{c}\text { NBS tarafından } \\
\text { açıklanan sayısal değer }\end{array}$ \\
\hline Az miktarda & $0.0-0.5$ \\
Hafif & $0.5-1.5$ \\
Hissedilir & $1.5-3.0$ \\
Sezilir & $3.0-6.0$ \\
Çok & $6.0-12.0$ \\
Çok fazla & $12.0-+$ \\
\hline
\end{tabular}

Akrilik ve silikon esaslı yumuşak astar materyalleri renk değişimi açısından karşılaştırıldığında, silikon esaslı yumuşak astar maddelerinin daha iyi renk stabilitesi gösterdiği saptanmıştır. Otopolimerize ve ıSı ile polimerize olan yumuşak astar materyalleri renk stabilitesi açısından karşılaştırıldıklarında sıklıkla ısı ile polimerize olan yumuşak astar materyalleri daha stabil bulunmuştur ${ }^{18,19}$. Bizim çalışmamızda da ISı ile polimerize olan silikon esaslı yumuşak astar maddesi olan ufigel $\mathrm{P}$ otopolimerize, akrilik esaslı yumuşak astar maddesi olan viskojelden daha iyi renk stabilitesi göstermiştir.

Silikon esaslı yumuşak astar materyallerinin yapıları yüksek sıcaklık, asit, baz gibi bir çok kimyasal reaksiyona akrilik esaslı yumuşak astar materyallerine göre daha dirençlidir. Ergün ve arkadaşları ${ }^{3,4}$ dört farklı yumuşak astar materyallerinin yaşlandırma sonrasında renk stabilitelerini inceledikleri çalışmalarında en fazla renklenmeyi Viscogel de en az renklenmeyi ise Vertex soft da tespit etmişlerdir. Sonuç olarak ISI ile polimerize olan yumuşak astar materyallerinin, kimyasal olarak polimerize olan yumuşak astar materyallerine göre daha iyi renk stabilitesine sahip olduğunu bildirmişlerdir ${ }^{3,4}$. Sonuçlar bizim çalışmamız ile paralellik göstermektedir.

In vivo ve in vitro çalışmaların önemli bir kısmında renk stabilitesinin ölçülmesinde spektrofotometreden yararlanılmıştır ${ }^{3,4}$. İnsan gözünün fark edebildiği ya da kabul edilebilir renk farklılığının sınır değeri farklı çalışmaların sonucunda farklı değerler olarak tespit edilmiştir. Kabul edilebilir değerler, $\Delta \mathrm{E}=1, \Delta \mathrm{E}$ $=2, \Delta \mathrm{E}=3$ arasl, $\Delta \mathrm{E}>3,3$ veya $\Delta \mathrm{E}=3,3$ ve $\Delta \mathrm{E}>3,7$ veya $\Delta E=3,7$ olarak belirtilmiştir ${ }^{16}$. (NBS) Standartlarına göre Goiato ve arkadaşları eğer renk değişim değeri $\Delta \mathrm{E}<1$ ise önemsenmez, $1<\Delta \mathrm{E}<2$ ise renk değişimi klinik olarak kabul edilebilir, $3,3<\Delta \mathrm{E}$ olduğunda ise gözle fark edilebileceğini bildirmişlerdir ${ }^{9}$. Yannikakis ve arkadaşları $^{20}$ ise çalışmalarında $\Delta \mathrm{E}<3,7$ değerin klinik olarak kabul edilebilir olduğunu bildirmişlerdir. Bizim çalışmamızda da viskojel çay, kahve grubu; kerr çay, kahve, portakal suyu, distile su grubu; elite soft çay kahve portakal suyu, distile su grubunda $\Delta \mathrm{E}$ değeri 24 saat sonunda ve 7 gün sonunda yapılan ölçümlerde 3,7 rakamının üzerindedir. Çalışmamızda ısı ile polimerize olan içeriğinde modifiye polidimethil siloksan ve platinyum katalist bulunan silikon esaslı bir yumuşak astar maddesi olan ufi gel permanent, içeceklerde 24 saat bekletme süresi sonunda 3,7 den daha düşük bir renk değişim değeri göstermiştir.

İmirzalioğlu ve arkadaşlarının ${ }^{21}$ ISl, kimyasal ve enjeksiyon yöntemiyle polimerize edilen akrilik rezinlerin ve yumuşak astar materyalinin dâhil edildiği çalışmalarında renklendirici içecek solüsyonu olarak; 1. grupta yapay tükürük(kontrol grubu), 2.grupta yapay tükürük +çay, 3. grupta yapay tükürük+ kahve, 4. grupta ise nikotin solüsyonu+ yapay tükürük kullanmışlardır. Grupları $37^{\circ}$ C'de karanlık ortamda muhafaza etmişlerdir. Kalorimetrik ölçümleri 1 saat, 7 saat, 3 günlük süre sonucunda yapılmıştır. Sonuç olarak renk değişimindeki farklar ise en fazla ISı ve enjekjeksiyon ile polimerize edilen akrilik rezinlerin kahve solüsyonunda, yumuşak astar materyallerinde ise nikotinde bekletilen yumuşak astar materyallerinde görülmüştür. Sonuçlar bizim çalışmamızla paralellik göstermektedir. Kahve en fazla renk değişimine sebebiyet veren içecektir.

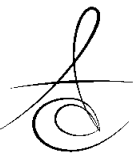


Bizim çalışmamızın limitasyonlarından biri ise normal ağız floarasının taklit edilememiş olmasıdır. Yapay tükrük içerisinde bulunan elementlerde yumuşak astar materyallerinin renk değişimine uğramasına sebep olabilir. Yapılan çalışmalarda yapay tükürük kullanılması ve termal siklus uygulanması gerçeğe en yakın sonuçlar elde edilmesini sağlayacaktır.

Yapmış olduğumuz çalışmada Türk halkının sıklıkla tükettiği içecekleri test etmek istedik, ancak nikotin solüsyonu kullanmadık. Bundan sonra yapılacak çalışmalar da dâhil edilmesi gereken önemli parametrelerden biride nikotin solüsyonudur.

Canay ve arkadaşları ${ }^{22}$; coe supersoft, flexor ve molloplast yumuşak astar materyallerini dâhil ettikleri çalışmalarında sentetik gıda boyası olan ve gıda kodeksinde müsaade edilen mamüllerle sınırlı miktarda kullanıma sahip eritrosin, tartrazin ve güneş sarısı renginin yumuşak astar maddeleri üzerindeki renk değişimini 1,3 ve 6 aylık bekletme süreleri sonucunda incelemişlerdir. Sonuç olarak en fazla renk değişim değeri 6 aylık bekletme süresi sonucunda güneş sarısı solüsyonunda bekletilen Coe süper soft yumuşak astar materyalinde gözlemiştir. Çalışmada kullanılan gıda boyaları dondurma, buzlu içecekler, şekerleme, jöle, aromalı içecek, sakız, pastacılık gibi birçok gıda üretiminde kullanılmaktadır. Bu sebeple gıda boyası içeren yiyecek ve içecekler konusunda hastalar bilgilendirilmeli ileride yapılacak olan çalışmalarda renklendirici gıdalarla birlikte, gıda boyaları da değerlendirilmelidir.

Ayrıca dental materyallerin renk değişiminde yüzey pürüzlülüğü de önemli bir parametredir. Oğuz ve arkadaşları ${ }^{23}$ yapmış oldukları benzer çalışmada yumuşak astar materyallerinin yüzey pürüzlülüğünü de ölçmüşlerdir. Sonuç olarak değişen farklı yüzey pürüzlülük değerlerinin yumuşak astar materyallerinin renk değişimini önemli ölçüde etkilediğini bildirmişlerdir. Bizim çalışmamızda örnekler aynı kalıplarda ve tek bir araştırmacı tarafından hazırlandığı için yüzey pürüzlülük değerlerine bakılmamıştır. Ancak farklı yüzey pürüzlülük değerlerine sahip aynı maddelerde farklı renk stabilite değerlerini görmek mümkündür. Bu sebeple daha sonra yapılacak olan benzer çalışmalar için yüzey pürüzlülük değerlerinin de dikkate alınması önerilmektedir.

Bu konu ile ilgili çalışmaların çoğu, bizim çalışmamızda dâhil olmak üzere in-vitro olarak gerçekleştirilmiştir. In-vivo araştırma sayısı çok azdır. Daha doğru bilgilere ulaşabilmek için konu ile ilgili uzun dönemli, klinik olarak hasta üzerinde yapılacak çalışmalara ihtiyaç vardır.

\section{SONUÇ}

$\mathrm{Bu}$ çalışmanın sınırları dâhilinde aşağıdaki sonuçlar çıkarılabilir:

1. Çalışmada kullanılan içecekler öğünlerde sıklıkla tüketilen içeceklerden seçilmiştir. Her bir içecek yumuşak astar materyallerinin renk stabilitesi üzerine farklı etki göstermiştir. Tüm materyal gruplarında çay ve kahve içecekleri anlamlı derecede yüksek renk değişimine neden olmuştur.

2. Test edilen her bir yumuşak astar materyalinin avantaj ve dezavantajları dikkate alınarak tedaviye uygun bir materyal seçilmelidir. Materyallerin olası renk değişimlerine karşı hastalar bilgilendirilmeli ve ağız hijyeni konusunda eğitilmelidir.

\section{KAYNAKLAR}

1.Yılmaz KS, Ozan O, Ramoğlu S, Aktöre H, Hamiş AO. The effect of denture cleansers on the color stability of soft denture lining materials. Atatürk Üniv. Diş Hek. Fak. Derg. 2015; 25: 59-65

2. Yamaner IDŞ, Tutal Z, Tuncer BE. Solubility of acrylic resins, soft denture relining materials and tissue conditioners. Atatürk Üniv. Diş Hek. Fak. Derg.2015; 25: 144-52

3. Ergün G, Nağaş IÇ. Color stability of silicone or acriylic denture liners: an in vitro investigation. Eur J Dent 2007;1:144-51

4. Ergün G, Nağaş IÇ. In vitro color stability of soft denture liners after accelerated aging. Hacettepe Diş Hek Fak Derg. 2007; 31:65-73

5.Nowakowska-Toporowska A, Raszewski Z, Wieckiewicz W. Color change of soft silicone relining materials after storage in artificial saliva. J. of Prosthet Dent. doi:10.1016/j.prosdent. 2015.08.022

6.Usumez A, Inan O, Aykent F. Bond strength of a silicone lining material to alumina-abraded and lased denture resin. J Biomed Mater Res B Appl Biomater 2004;71:196-200.

7. Karakış D, Akay C, Erdönmez D, Doğan A. Evaluation of Candida albicans biofilm formation on different soft lining materials. Acta Odontol Turc 2015;32:19-25 
8.Soygun K, Bolayır G, Dogan A, Demir H, Dogan M, Keskin S. Effect of surface treatments on tensile bond strength between a silicone soft liner and heat-cured denture base resin. J Adhes 2011;87:951-65.

9. Mancuso DN, Goiato MC, Zuccolotti BC, Moreno A, dos Santos DM, Pesqueira AA. Effect of thermocycling on hardness, absorbtion, solubility and color change of soft liners. Gerodontology 2012;29:215-9

10. Saraç D, Saraç YS, Kurt M, Yüzbaşıoğlu E. The effectiveness of denture cleansers on soft denture liners colored by food colorant solutions. J Prosthodont 2007;16:185-91

11. WF. Sepúlveda-Navarro, BE. Arana-Correa, C.P. Borges, JH. Jorge, VM. Urban, N.H. Campanha. Color Stability of Resins and Nylon as Denture Base Material in Beverages. J Prosthodont. 2011;20:632-8

12. Bayındır F, Kürklü D, Yanıkoğlu D.N. The effect of staining solutions on the color stability of provisional prosthodontic materials. J. Dent. 2012;40:41-6

13.Polyzois G, Kostoulas I, Nikolovieni D, Mitsoudis A. Frangou M. Color changes of autopolymerized silicone or acrylic soft denture reliners: the effect of accelerated aging. Odontology; 2013;101:193-8

14.Leite VM, Pisani MX, Paranhos HF, Souza RF, SilvaLovato $\mathrm{CH}$. Effect of ageing and immersion in different beverages on properties of denture lining materials. J Appl Oral Sci 2010;18:372-8.

15. Handa RK, Jagger DC, Vowles RW. Denture cleansers, soft lining materials and water temperature: what is the effect?. Prim Dent Care 2008;15:53-8.

16.Anıl N, Hekimoğlu C, Şahin S. Color stability of heat-polymerized and autopolymerized soft denture liners. J Prosthet Dent 1999;81: 481-4

17. Türker BŞ, Buğurman B, Şener DI, Akkuş E. In vitro color stability of silicon-based denture relining materials. Atatürk Ünv Diş Hek Fak Derg 2008;18: 53-9

18. Hollis S, Eisenbeisz E, Versluis A. Color stability of denture resins after staining and exposure to cleansing agents. J. Prosthet. Dent. doi:10.1016/ j.prosdent.2015.06.001

19.Niarchou A, Ntala P, Pantopoulos A, Polyzois G, Frangau $M$. Effect of immersion cleansing in color stability and hardness of soft denture reliners. J Craniofac Surg 2012;23:426-9

20.Yannikis SA, Zissis AJ, Polyzois GL, Caron C. Color stability of provisional resin restorative materials. J Prosthet Dent 1998;80:533-9

21. Imırzalioğlu P, Karacaer O, Yılmaz B, Ozmen I. Color Stability of Denture Acrylic Resins and a Soft Lining Material Against Tea, Coffee, and Nicotine. J Prosthodont 2010;9:118-24

22. Canay S, Hersek N, Tulunoğlu I, Uzun G. Evaluation of colour and hardness changes of soft lining materials in food colorant solutions. J. Oral Rehabilitaton 1999;26:821-9

23. Oğuz S, Mutluay MM, Doğan OM, Bek B. Color change evaluation of denture soft lining materials in coffe and tea. Dent. Mater J 2007;26:209-16

\section{Yazışma Adresi:}

Yrd. Doç. Dr. Canan AKAY

Osmangazi Üniversitesi

Diş Hekimliği Fakültesi

Protetik Diş Tedavisi Anabilim Dalı

Meşelik Kampüs, ESKİŞEHİR

TIf: 05303338626

0222-2393750-1467

e-mail: cnngcr2@hotmail.com 